\title{
Dams in South Europe: socio-environmental approach and eDNA-metabarcoding to study dam acceptance and ecosystem health
}

\author{
Sara Fernandez (E) Elena Arboleya $\cdot$ \\ Eduardo Dopico · Eva Garcia-Vazquez
}

Received: 27 April 2021 / Accepted: 3 February 2022 / Published online: 21 February 2022

(C) The Author(s) 2022

\begin{abstract}
Under current climate warming, dams and reservoirs are main options to ensure water supply in dry regions. However, the presence of these infrastructures encompasses impacts on ecosystem due to the alteration of connectivity and river habitat. We expect that as a result of the relation between water supply as a resource and the population will depend on their use or demand, so the benefits of dams compensate their negative impacts in regions with droughts while not having the same perception in zones where water supply is not a problem, so the public acceptance of dams is expected to change depending on the area. Here, we have employed a multidisciplinary approach to study dam acceptance and also measure ecosystem health in two dammed areas, Guadalhorce and Nalón rivers, Mediterranean
\end{abstract}

Supplementary Information The online version contains supplementary material available at https://doi. org/10.1007/s11273-022-09864-6.

\section{S. Fernandez $(\square)$}

Marine and Freshwater Research Centre, School of Science and Computing, Galway Mayo Institute of Technology, Dublin Road, Galway H91 T8NW, Ireland e-mail: fernandezfsara@uniovi.es

S. Fernandez $\cdot$ E. Garcia-Vazquez

Department of Functional Biology, University of Oviedo, Avda. Julian Clavería s/n, 33006 Oviedo, Spain

E. Arboleya · E. Dopico

Department of Education Sciences, University of Oviedo, Aniceto Sela s/n 33005, Oviedo, Spain dry south and Atlantic humid north of Spain, respectively. The methodology employed has included the use of Environmental DNA for phytoplankton inventory and surveys to stakeholders and ordinary citizens to measure dam's acceptance. Worse bioindicators of water quality associated to dams were found in Guadalhorce than in Nalon River. However, stakeholders valued more the ecosystem services provided by Guadalhorce dams, especially of cultural nature, than those provided by Nalón dams. Most citizens consulted $(\mathrm{N}=319$ and 300 in Guadalhorce and Nalón regions) were favourable to the presence of dams and reservoirs. They would also increase their annual taxes to restore river connectivity, especially in Guadalhorce River, while dam demolition was the least supported. The generally positive views would help to identify actions for improvement of dammed rivers highlighting the importance of restoring river connectivity without dam demolition for local river users.

Keywords Dammed rivers · Ecosystem health · eDNA metabarcoding · Bioindicators · Ecosystem services · Willingness to pay

\section{Introduction}

Rivers connectivity is a basic feature that needs to be conserved although historically humans have disrupted the river flow to use the resources provided by the ecosystem (Pringle 2003). Dams and 
reservoirs are the main source of drinking water for the surrounding populations; however, these infrastructures cause a big damage in the system (Crook et al. 2015), what entails a conflict between the river exploitation and the maintenance of ecosystem health (World Commission on Dams 2000). In impassable dams where river connectivity is completely blocked, upstream river courses are devoid of migratory species that cannot reach upper river areas, impoverishing diversity as well (Reyes-Gavilan et al. 1996; Mcallister et al. 2001; Han et al. 2008; Limburg and Waldman 2009; Horreo et al. 2011). Other negative effects of both passable and impassable dams are due to the transformation of dammed river areas into lentic zones due to abnormal flow regimes, with intense sedimentation and suspended material (McCartney 2009). This affects plankton reducing diversity while opportunistic and potentially harmful phytoplankton species may appear (Mcallister et al. 2001; Okuku et al. 2016) causing deep ecosystem changes from the bottom of the trophic chain that may endanger the whole aquatic community.

Even when rivers suffer serious biological alterations and their courses are dramatically altered, dams and reservoirs are necessary to supply water to the population (Malmqvist and Rundle 2002). In a planet that suffers the strong impacts of global warming, having dams for water storage seems reasonable. All the inhabitants in a region benefit from the energy and drinking water, but those living nearby dams and reservoirs have perhaps a different perspective because they are directly affected by the consequences of the specific ecosystem changes. The environmental impacts of dams cause controversy and may generate conflicts, especially in the areas directly affected (Boyé and Vivo 2016). Although making the reduction of the environmental impact of artificial barriers compatible with the economic benefits of water exploitation is part of the EU Water Framework Directive 2000/60 (Official Journal of the European Communities, 327, 22.12.2000, pp. 1-73), the truth is that barely half of the surface waters in the EU met this objective (European Environment Agency 2018). Solutions to the mentioned alterations may imply substantial changes of big impact (like dam demolition) or smaller improvements like the creation of fish passages, or restoration of natural wetlands upstream or downstream dams (Arthington et al. 2010; Sneddon et al. 2017). All the actions to restore rivers require political decisions and effort, whether bigger or smaller, of public managers and private users. Citizens' support can be substantial, but studies about the social acceptance of dams and of different measures to improve their services or mitigate their impacts are, however, scarce.

Being a complex issue that encompasses social and environmental aspects, there is a need for a multidisciplinary approach. River restoration plans should be based on ecological monitoring together with economic and social analysis (Rodeles et al. 2017). Taking into account that complexity, here we have employed a multidisciplinary set of tools in Guadalhorce River within SW Mediterranean basin (Andalusia, south Spain) and in Nalón River within south Bay of Biscay (Asturias, north Spain) to investigate how dams and reservoirs affect ecosystem health. Molecular tools based on environmental DNA to inventory phytoplankton species (Rivera et al. 2018; Ardura et al. 2020) were applied to assess water quality in dammed areas. Participatory approach to determine services and disservices provided by dams and reservoirs involving relevant stakeholders, and a social survey on social acceptance of dams including willingness to pay, were conducted following a face-to-face application model (Vandenplas and Loosveldt 2017). The application of these tools combined will help to estimate the value of different ecosystem health components and advice measures to improve the management of disrupted rivers. Expectations were that the dams and reservoirs would be more appreciated in Guadalhorce River than in Nalón River, and residents in the vicinity of reservoirs would be more favourable to them as a result of being part of a dryer area of the country where drinking water is sometimes a scarce resource.

\section{Materials and methods}

\section{Ethical statement}

The Research Ethics Committee of the Principality of Asturias approved the study with the reference 101/16. All information collected from questionnaires was anonymous and used exclusively for research purposes. The participants gave their consent and were informed that they could withdraw from this 
study at any moment and have access to the results obtained.

\section{Study areas}

The Mediterranean River Guadalhorce, province of Málaga, Andalusia (Spain), has an irregular regime alternating frequent droughts and occasional flash floods that cause extensive damage and threaten human lives. The river supplies water and electricity to the city of Málaga via four hydropower stations on the same number of dams and reservoirs that also regulate water flow (Fig. 1), the biggest dams were constructed between 1914 and 1966. It is the main fluvial basin of south Mediterranean Spain, with a Mediterranean climate of Csa subtype, a mean annual temperature of $18.4{ }^{\circ} \mathrm{C}$ and $520 \mathrm{~mm}$ of pluviosity. Csa is a type of hot-summer Mediterranean climate within Köppen-Geiger system, characterized by: Having the coldest month averaging above -3 to $0{ }^{\circ} \mathrm{C}$ (27 to $32^{\circ} \mathrm{F}$ ), at least one month's average temperature above $22{ }^{\circ} \mathrm{C}\left(71.6^{\circ} \mathrm{F}\right)$, and at least four months averaging above $10{ }^{\circ} \mathrm{C}\left(50^{\circ} \mathrm{F}\right)$; at least three times as much precipitation in the wettest month of winter as in the driest month of summer, and driest month of summer receives less than $40 \mathrm{~mm}$ (Beck et al. 2018).

The river channel has been diverted in Málaga city to prevent inundations and decrease flood risk. It contains elements of social importance and historical relevance, such as the remains of the Phoenician archaeological site called "Cerro del Villar", inventoried as Historical Patrimony (http://www.iaph.es/patrimonioinmueble-andalucia/resumen.do?id=i7954) that are located near the river mouth. Between the two delta branches there is a protected wetland, special zone of bird protection (Paraje Natural Desembocadura del Guadalhorce), which is the last shelter of migratory birds still left in the very touristic coast of Málaga province. In Málaga city there are two water treatment plants, and the habitants of the province were 1641 in 2018.

The River Nalón is located in the central area of south Bay of Biscay and crosses the region of Asturias. Asturias is characterized for having a temperate climate that is gradually changing with temperature increases as in other parts of the world. This river has seven large dams and reservoirs built between 1960 and 1970, two of them (Tanes and Rioseco) within a protected area upstream-Redes Natural Park that
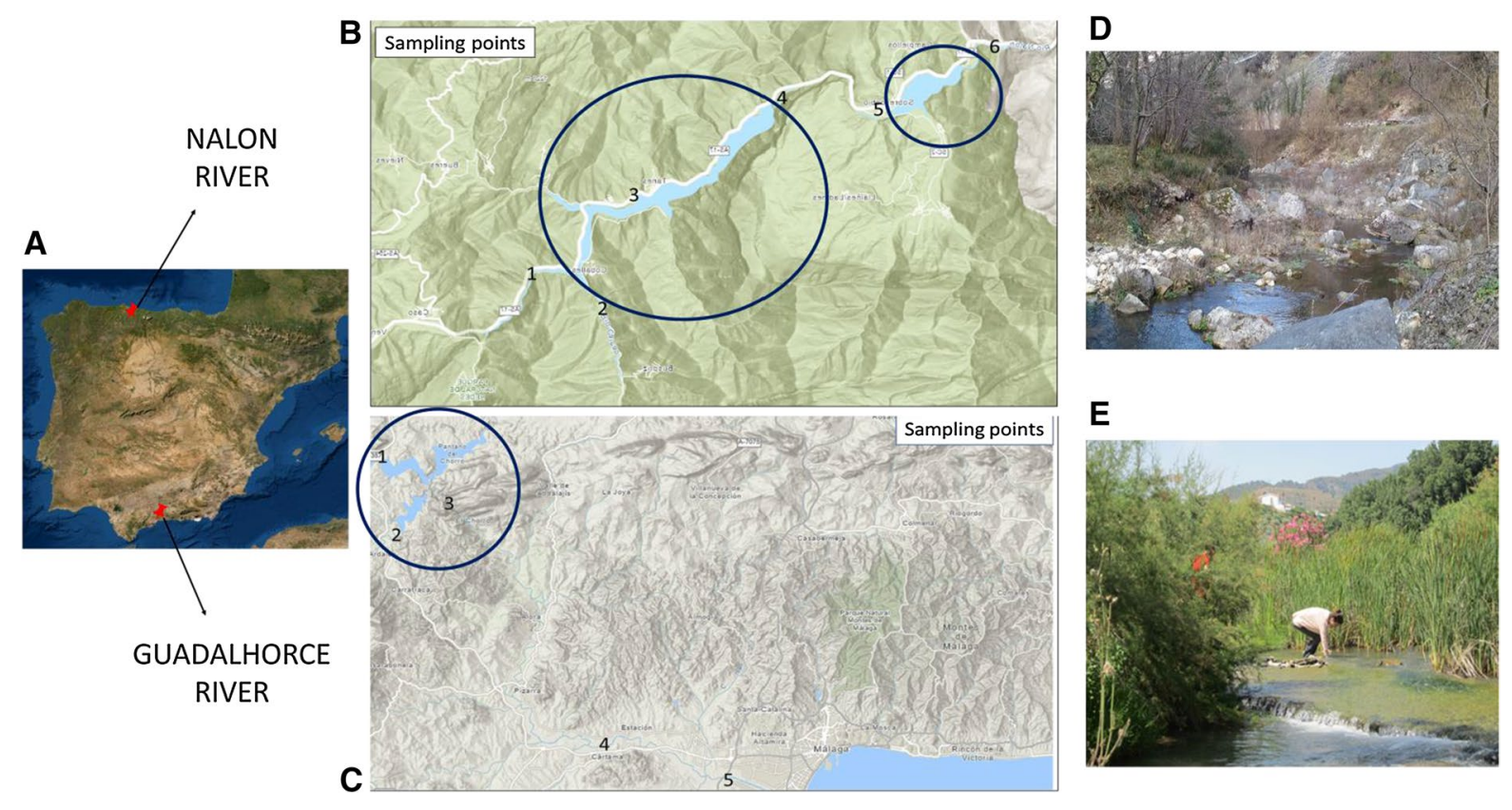

Fig. 1 Map showing the location of Guadalhorce and Nalón rivers in Iberian Peninsula (A). Map of the areas affected by dams in each river; sampling sites are numbered (B: Nalón; $\mathbf{C}$ :
Guadalhorce). D and $\mathbf{E}$ photographs show views of river zones showing typical riverine ecosystems between dams in the two riversBlue circles are highlighting the reservoirs 
is a Natura 2000 site and Reserve of the Biosphere (García-Ramos et al. 2006). The main uses of the dams are providing energy and drinking water to the central part of the region and also regulate the excess of water downstream to avoid floods when necessary. The dominant fish species within this protected area is brown trout (Salmo trutta) and prior to the construction of the dams, European eel and Atlantic salmon could still reach the highest part of the river. However, nowadays, these valuated species can only be found in the lowest part of the system. Here, we will focus on the upper part of the river, where the connected reservoirs of Tanes and Rioseco provide drinking water and energy to the central part of the region.

\section{River management plans}

In Guadalhorce River, the construction of an additional water treatment plant was planned near the river mouth in Málaga city, together with several modifications of the river course and riverbed in this area like channelization and water diversion, and a runway considered a barrier for river species by conservationists. These plans had created conflicts with environmentalist NGOs (non-governmental organization) and other stakeholders like landowners. The plan of building a large water treatment plant was changed in 2017 for the construction of one smaller treatment facility to serve the villages of Alhaurín el Grande and Cártama. Later changes included alternative, softer and cheaper project for the river channel modification that was presented in the City Council of Málaga City on March the 1st, 2019. As the old plan, its purpose was to solve the current problem of flooding in the lower part of the river that especially affects the delta. The new project comprises several small to moderate actuations in the flood plain and has been prepared by IRTENE Consulting. Six actuations were approved by Málaga City Council: regrowth the left margin of Prado de Jurado, de las Yeguas, Boticario y Pocapringue channels; reconditioning the channel of the main river near Málaga-Fuengirola railway; restoration of the riverbed near M-21 bridge; reduction of riverbed elevation in several parts of the river channel; regrowth some parts of the main river channel; cleaning up and restoration of several river zones. The plan approval by the Regional Government of Andalusia is still pending.
In Nalón River, a new dam (Caleao) was projected upstream within the protected area, for water and energy supply, including water supply for steel companies (specifically Arcelor-Mittal), and for compensatory flows to maintain biodiversity (enhancing water quality up to be apt for salmonids downstream). The project was cancelled officially after a decision of Asturias Parliament in 2018.

Stakeholder network to estimate ecosystem services and disservices

Following a participatory approach, local stakeholders were identified, and contacts established to initiate networking with them. The following stakeholders working on different aspects of Guadalhorce River were contacted: Junta de Andalucía (Regional Government of Andalusia); EU H2020 project SWOSSatellite-based Wetland Observation System; NGO Ecologistas en Acción (it could be translated as "Ecologists in Action"); NGO SEO-Birdlife (Spanish society of ornithology); University of Málaga, Center of Hydrogeology and European Topic Center. In the Junta de Andalucia the following Services were contacted: Subdirección de Explotación ("Subdirection of Exploitation"); Servicio DPH y Calidad de Aguas de la Delegación Territorial de Medio Ambiente (water quality service of the regional environmental office); Subdirección General de la Demarcación Hidrográfica del Sur ("General Subdirectorate of the Southern Hydrographic Sector"). With the help of local stakeholders, ecosystem services and disservices were estimated. Collaboration for field research and the social survey was also obtained in the context of this networking. In Asturias region the following stakeholders participated in the evaluation of dams' services: Regional Government of Asturias (Consejería de Infraestructuras, Ordenación del Territorio y Medio Ambiente, which is the section in charge of infrastructures, territory organization and environment in the Regional Government), University of Oviedo, EDP Energía (electricity operator through the reservoirs on the Nalón river), the Consortium for the Water Supply and Sanitation of Asturias (CADASA), the City Councils of high Nalón (Caso, Laviana and Sobrescobio) and the Friends of the River Nalón Anglers' Association.

Ecosystem services and disservices were classified based on the Common International Classification of 
Ecosystem Services (CICES V4.3; spread sheet version available at https://cices.eu/resources/, accessed August 2020). Values between 0 and 2 were assigned to each service above and below dams with the help of the involved stakeholders. For each service scores were weighted using a 0 to 1 scale of certainty. The change in ecosystem services is the difference (after-before) dams' construction (Table 3). Consensus scores and certainty values were employed.

The results obtained in this study were presented publicly in Málaga, Spain at the Symposium on Connectivity in Mediterranean rivers held on Tuesday, September the 3rd, 2019 in the Ada Byron Building of the University of Málaga. Attendants represented the main sectors involved in river management and use. Local stakeholders that have networked and collaborated with researchers helped in the organization of the workshop. In Asturias they were presented in a workshop held in the affected area, Rioseco Village was the place chosen to disseminate those results and several activities involving children were prepared. This was part of the event World Fishing Migration Day (https://worldfishmigrationdayfeedback.wordp ress.com/portfolio/spain-3/).

\section{Social survey}

Residents in the case study zones were contacted directly by the researchers near the sampling points (local users of the dams/reservoirs) and in Málaga (Guadalhorce) and Oviedo and Gijón (Nalón) cities, as samples of the general population in the provinces. The researcher wore neutral clothes for not influencing the respondent's opinion and just explained briefly the project objectives. A question about the dam acceptance with five answer options was posed as it follows:

What is your opinion about dams and reservoirs in Gualdalhorce/Nalón River? Please choose one of these options: (a) They should be eliminated, (b) I would prefer them out of the area where I am living, (c) Should be modified for having less ecological impact, (d) Should be maintained as they are today, (e) More dams and reservoirs are needed to provide more services.

Ecosystems provide us with well-being and their preservation can be encouraged through payments to tax their use (Vandenplas and Loosveldt 2017). A specific question was dedicated to investigating the willingness of the interviewees to pay additional taxes to improve rivers through different actions. The willingness to pay was measured from the following question: What taxes percentage (\%) you pay yearly you would allocate to: (a) Building structures to facilitate fish migration; (b) Improving the economic efficiency of the reservoir (leisure, fishing, water reserves...); (c) Improving waters connectivity / rivers reconnection; (d) Contributing to dam and reservoirs demolition; (e) Building new dams and reservoirs. A scale $1-5$ for $0 \%, 0.1-0.5 \%, 0.5-1 \%, 1-5 \%$ and other (higher) \% was employed. Questions (a) and $(c)$ imply actions to improve the ecological status of the river that do not involve dam demolition. Question $b$ involves changes in the human use of reservoirs. Questions $d$ tackles directly the issue of dam demolition, while a high payment will in $e$ would reflect a high appreciation of services provided by these infrastructures.

\section{Determination of river environmental health from} DNA metabarcoding

Water quality is the main feature measured when assessing the ecological status of aquatic systems (von der Ohe et al. 2007). These estimations can give an overview of the ecosystem health. There are different ways of measuring water quality, from physiochemical measures to biological indicators (Armitage et al. 1983; Kim et al. 2015). Among the last ones, algae, and especially diatoms, are employed to assess water quality based on their resistance to pollution and preference of trophic water status (Descy and Coste 1991; Kelly et al. 2008; Dell'Uomo and Torrisi 2009; Feio et al. 2012; Singh et al. 2013; Cimarelli et al. 2015; Petr et al. 2017). They are generally visually identified from morphological traits or cultures, but nowadays DNA-based methodologies are increasingly being applied in the study of those organisms for being precise and cost-efficient (Cimarelli et al. 2015; Vasselon et al. 2017). High-throughput sequencing (HTS) technologies applied on environmental samples (eDNA metabarcoding) may be used as a shortcut to estimate biological indices of water quality (Rivera et al. 2018; Fernández et al. 2018, 2019b). Metabarcoding using a fragment from the chloroplastic gene Ribulose bisphosphate carboxylase 
large chain (RbcL) for diatom identification has been already employed for evaluation of lake water quality (Rivera et al. 2018), and the same methodology has been also recently applied to detect nuisance algae from ballast water (Ardura et al. 2020).

\section{River sampling sites and samples processing}

Five key sampling sites were chosen along Guadalhorce River with the valuable help of local stakeholders (Fig. 1). Site\#1 was upstream, out of the influence of the reservoirs, and the rest were located in running waters between dams (Site\#2), just below (Site\#3) and downstream the lowest dam (Site\#4) and near the river mouth after the river channel diversion (Site\#5). Three bottles of 1L each were taken on each site. Water samples were vacuum-filtered the same day of collection, immediately after arriving to the laboratory in the city of Málaga, they were kept in ice during transporting. A Supor® 200 Membrane Filter (Pall Corporation, Life Sciences) with $0.2 \mu \mathrm{m}$ pore size and $47 \mathrm{~mm}$ diameter was used. Water samples were filtered in a room separated from the molecular laboratory in which only water samples are handled. The filtration apparatus was cleaned with $10 \%$ bleach (5\% sodium hypochlorite concentration), triple-rinsed with DI water, and then exposed to $20 \mathrm{~min}$ of UV light in a PCR cabinet (normally utilized for pre-PCR experiments) between samples to prevent contaminations. The DI water carried to the field (negative field control) was filtered last, after the rest of river water samples. Finally, one litre of DI water was filtered as filtering negative control. Filters were manipulated with previously decontaminated (cleaned with bleach and UV as the filtration apparatus) forceps to place them in storage tubes. The filters were preserved in $100 \%$ ethanol. Environmental DNA was extracted from filters (one extraction per filter) using PowerWater® DNA Isolation Kit (MoBio Laboratories) under controlled airflow conditions using a laminar flow PCR cabinet. A negative control to check possible laboratory or cross-contamination was included in the extraction process and analysed together with the rest of the samples. The extraction followed the manufacturer's instructions.

Details regarding Nalón samples collection and processing can be found at Fernandez et al. (Fernández et al. 2019b). Briefly, the sampling area is in the Upper Nalón River around Tanes and Rioseco reservoirs. Sites \#1 and \#2 are located in two independent streams that flow separately in Tanes reservoir. Site \#3 is located in a third small stream discharging in the mid part of Tanes reservoir. Site \#4 is just below the dam of Tanes reservoir, and Site \#5 on the tail of Rioseco reservoir, and Site\#6 downstream Rioseco reservoir. The procedure of water collection, number of replicates and laboratory protocols were the same as described for Guadalhorce River.

\section{DNA metabarcoding procedures}

The extracted DNA was sent to Macrogen (Seoul, Korea) for further analysis. The DNA was quantified by a fluorescence-based method Victor 3 (Picogreen, Invitrogen). A fragment of 312 bp within the plastid RbcL gene was PCR amplified using DiatRbcL-708F (5' AGGTGAARYWAAAGGTTCWTA YTTAAA 3') and Diat-RbcL-R3 (5' CCTTCTAAT TTACCWACWACWG 3') designed for diatom identification (Vasselon et al. 2017). Amplicon PCR (1st PCR) thermocycling conditions were: $95{ }^{\circ} \mathrm{C} 5 \mathrm{~min}$, 30 cycles of $95{ }^{\circ} \mathrm{C} 45 \mathrm{~s}, 55^{\circ} \mathrm{C} 45 \mathrm{~s}, 72{ }^{\circ} \mathrm{C} 45 \mathrm{~s}$ and a final extension of $72{ }^{\circ} \mathrm{C}-10 \mathrm{~min}$. The primers were modified to include IlluminaTM overhang adaptors and sample-specific indices following the dual-PCR Illumina protocol (https://support.illumina.com/). In addition, bovine serum albumin (BSA) was added to the PCR reactions to increase PCR yields from low purity templates and to avoid, as much as possible, the effect of inhibitors presents in the water. After library construction, MiSeq Illumina platform was employed to run the sequencing step using pairedend sequencing $(2 \times 300)$. Adapters and indices were removed from the raw data along with reads $<36 \mathrm{bp}$ using the Scythe and Buffalo software, respectively. As in other NGS metabarcoding studies (Cowart et al. 2018; Port et al. 2016), negative controls were not included in the sequencing run because there was no evidence of contamination in the PCR step.

Illumina Paired-End raw files consisting of forward (R1) and reverse (R2) reads were sorted (demultiplexed) by library and quality scores. Indices and sequencing primers were trimmed during the demultiplexing step. The raw FASTQ files can be accessed at NCBI, SRA database with the Bioproject accession number PRJNA690673; Biosample: SAMN17256641. 
R wrapper JAMP v0.67 (https://github.com/ VascoElbrecht/JAMP) was employed to quality filter the data: sequences were merged using Usearch v11.0.667_i86 (Edgar, 2010) allowing for a 25\% mismatch in overlap (setting "-fastq_maxdiffs 99 -fastq_ pctid 75 -fastq_trunctail 0" as thresholds). Primers were trimmed and sequences were filtered by length (amplicon size $312 \pm 10$ bp reads were retained) using Cutadapt v1.15 (Martin 2011). Expected errors probabilities were calculated to filter reads qualities (Max ee $=0.5$; -fastq_qmax 60) using Usearch v11.0.667_ i86 (Edgar 2010). Denoising option was employed within JAMP pipeline, where sequences are dereplicated and denoised using the unoise 3 algorithm from Usearch v11.0.667_i86 (Edgar 2010) and clustered at $30 \%$ similarity. Then, molecular operational units (OTUs; putative species) below $0.01 \%$ abundance are discarded, as well as haplotypes below $0.003 \%$.

\section{Taxonomic assignment}

After the filtering steps, the sequences were assigned taxonomically using a locally stored reference database downloaded from the NCBI on the 16/06/2020 using the e-search query "rubisco rbcl NOT uncultured NOT unclassified". To construct the database, that includes the accession numbers and taxonomy information from NCBI, the script "Entrez_qiime. py" by Baker et al. (2017) was employed. Then filtered sequences were compared against this database to assign each sequence to a species whenever possible. For this the script employed was "qiime feature-classifier" within QIIMETM 2 pipeline v2020.2 (Bolyen et al. 2019), using BLAST algorithm, with the thresholds of $97 \%$ nucleotide identity percentage and E-value of $10^{-50}$. This means that a sequence with $<97 \%$ identity with any of the sequences present in the reference database will appear as unassigned. If a sequence is assigned to more than one species with $>97 \%$ identity, it will be assigned to a genus level, or lower (family, order) if the information is not enough to reach the genus level.

The resulting list of OTUs was exported as a spreadsheet table, to be edited and statistically analysed using Microsoft Excel version 2016. A manual expert check was done to avoid erroneous assignations due to outdated taxonomy (it may happen in old references). Here taxonomy followed Algaebase (Guiry et al. 2014).
As a final step, the resulting OTU tables from the three replicates of each sampling point were merged for further analyses.

\section{Bioindicators of river ecosystem health}

Microalgae identified from $\mathrm{RbcL}$ metabarcode were classified according to their value as indicators of water quality based on EPI-D index specifically applied to Mediterranean rivers, following Dell'Uomo and Torrisi (2009). There are species characteristic of very bad (12 species), bad (7 species), mediocre (8 species), good ( 9 species) or excellent (10 species) water quality; the species most resistant to pollution and hypertrophic conditions can grow in bad quality waters, while sensitive species can only grow in waters of good quality.

In addition, considering that metabarcoding relies upon reference databases, we have chosen a subset of nine species for which there are many DNA references used by Cimarelli et al. (2015) as bioindicators. These are selected from the classes of water quality identified by the European Water Framework Directive, and classified as indicators of excellent-good (Achnanthidium minutissimum (Kützing) Czarneck), good-mediocre (Cyclotella meneghiniana (Kützing), Nitzschia dissipata (Kützing) Grunow), mediocre (Surirella angusta Kützing), bad (Nitzschia palea (Kützing) W Smith) or bad-very bad (Craticula halophila (Grunow ex Van Heurck) Mann, Mayamaea atomus var. permitis (Hustedt) Bruder \& Medlin, Navicula veneta (Kützing)) water quality (Cimarelli et al. 2015).

\section{Statistics}

Taxonomic diversity in each sampling site was measured using Shannon index with the number of species per class as unit. Non-metric multidimensional scaling (3D, Euclidean distance) was employed to visualize the differences in community species detected from metabarcoding OTUs in the sampling sites.

Differences in willingness to pay for an action between different actions on dams were tested using two-way ANOVA, after checking normality with Shapiro-Whilk and homoscedasticity with Breusch-Pagan test.

All statistical analyses were implemented in PAST software (Hammer et al. 2013). 


\section{Results}

Ecosystem alterations inferred from metabarcoding

HTS from water samples with RbcL metabarcode yielded a total of $1,241,083$ and 744,195 reads for Nalón and Guadalhorce Rivers respectively. After applying quality filters were reduced to 1,044,264 and 545,335 (Supplementary Table 1). The number of OTUs assigned down to a genus or species level was 60 (of which 52 at species level) of freshwater phytoplankton (Table 1, Supplementary Table 2).

Algae diversity is severely altered by the dams (Okuku et al. 2016), and in this study it was clearly different among sampling points (Table 1), with a sharp decline in the locations between dams and some recovery downstream in the Guadalhorce River where G\#2 was the least diverse site. Shannon diversity was zero there with all the species belonging to the order Bacillariales. In the case of Nalón River, the lowest diversity corresponded to sample N\#3 close to Tanes dam, but diversity increased between dams and downstream with enrichment in Xantophyceae (Table 1).

Despite very different ecological conditions of Guadalhorce and Nalón rivers that are reflected in many samples well separated, the samples most affected by dams in the two rivers (G\#2 and G\#3 in Guadalhorce; N\#4 between dams and N\#6 just downstream Nalón) were closely located in the NMDS (Fig. 2). With a reasonable non-significant stress of $0.06, \mathrm{r}^{2}$ of axis 10.768 and of axis 20.157 ), a clear

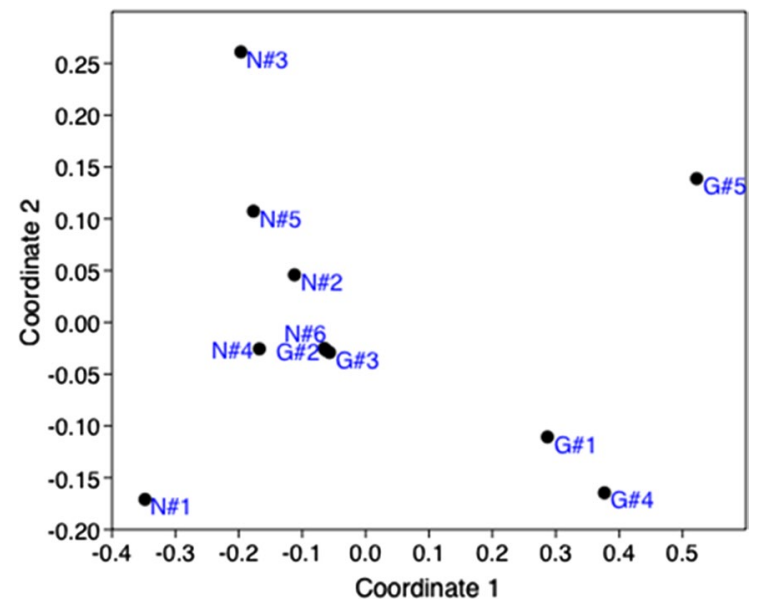

Fig. 2 NMDS scatter plot representing the communities detected from RbcL metabarcode from the sampling points analysed within Guadalhorce (G\#1-G\#5) and Nalón (N\#1$\mathrm{N \# 6)} \mathrm{rivers}$

lack of connectivity was reflected in the lack of internal order of the sampling points along each river, with upstream locations obviously separated of the next point downstream.

A negative effect of dams on water quality could be also detected in Guadalhorce and Nalón rivers. Several biological indicators of environmental status were found with RbcL metabarcode: seven species from Dell'Uomo and Torrissi (2009) panel and seven from Cimarelli et al. (2015) list, the majority indicators of bad water quality, a few of good or mediocre and none of excellent quality (Table 2).
Table 1 Summary of algae diversity found from RbcL metabarcode in Guadalhorce and Nalón rivers

Data presented per sampling site the number of OTU (putative species) of each class found in the study, the putative species richness and the taxonomic diversity (Shannon index)

\begin{tabular}{|c|c|c|c|c|c|c|c|c|c|c|c|}
\hline & \multicolumn{5}{|c|}{ Guadalhorce River } & \multicolumn{6}{|c|}{ Nalón River } \\
\hline & G\#1 & $\mathrm{G} \# 2$ & $\mathrm{G} \# 3$ & G\#4 & $\mathrm{G} \# 5$ & $\mathrm{~N} \# 1$ & $\mathrm{N \# 2}$ & $\mathrm{N \# 3}$ & $\mathrm{N \# 4}$ & N\#5 & N\#6 \\
\hline Bacillariophyceae & 28 & 16 & 25 & 7 & 11 & 49 & 58 & 65 & 42 & 45 & 21 \\
\hline Coscinodiscophyceae & 1 & 0 & 2 & 0 & 2 & 2 & 3 & 1 & 3 & 2 & 1 \\
\hline Fragilariophyceae & 2 & 0 & 3 & 1 & 1 & 3 & 3 & 2 & 3 & 4 & 3 \\
\hline Mediophyceae & 3 & 0 & 3 & 5 & 5 & 0 & 5 & 0 & 4 & 3 & 5 \\
\hline Chlorophyceae & 0 & 0 & 0 & 0 & 0 & 0 & 1 & 0 & 0 & 0 & 0 \\
\hline Cryptophyceae & 2 & 0 & 1 & 0 & 0 & 0 & 0 & 0 & 0 & 1 & 0 \\
\hline Euglenophyceae & 1 & 0 & 0 & 0 & 0 & 0 & 0 & 0 & 0 & 0 & 0 \\
\hline Eustigmatophyceae & 0 & 0 & 0 & 0 & 0 & 0 & 2 & 1 & 2 & 2 & 2 \\
\hline Phaeophyceae & 0 & 0 & 0 & 0 & 0 & 1 & 2 & 1 & 1 & 1 & 0 \\
\hline Xantophyceae & 0 & 0 & 0 & 0 & 0 & 0 & 2 & 1 & 5 & 2 & 2 \\
\hline Species richness & 37 & 16 & 34 & 13 & 19 & 55 & 76 & 71 & 60 & 60 & 34 \\
\hline Taxonomic Shannon & 0.93 & 0.00 & 0.92 & 0.90 & 1.06 & 0.45 & 0.98 & 0.42 & 1.12 & 1.02 & 1.23 \\
\hline
\end{tabular}


Table 2 Key indicator species identified from their DNA using RBLC metabarcode from Guadalhorce and Nalón rivers, as number of sequences assigned to a species in each river
a'Dell'Uomo and Torrissi (2009)

${ }^{\mathrm{b}}$ Cimarelli et al. (2015)

\begin{tabular}{lllllr}
\hline Species & EPI-D $^{\mathrm{a}}$ & Molecular panel $^{\mathrm{b}}$ & Consensus & Guadalhorce & Nalón \\
\hline Achnanthidium minutissimum & & Excellent-good & Excellent & 0 & 3651 \\
Caloneis amphisbaena & Bad & & Bad & 48 & 0 \\
Cocconeis pediculus & Mediocre & & Mediocre & 0 & 471 \\
Cyclotella meneghiniana & Bad & Good-Mediocre & Mediocre & 64,958 & 2811 \\
Cymatopleura solea & Mediocre & & Mediocre & 161 & 258 \\
Entomoneis paludosa & Very bad & & Very bad & 498 & 0 \\
Mayamaea permitis & & Bad-very Bad & Bad & 138 & 1124 \\
Navicula phyllepta & Very bad & & Very bad & 48 & 0 \\
Navicula veneta & Very bad & Bad-very Bad & Very bad & 102 & 17 \\
Nitzschia dissipata & & Good-mediocre & Good & 49 & 20,214 \\
Nitzschia palea & & Bad & Bad & 5447 & 5181 \\
Surirella angusta & & Mediocre & Mediocre & 447 & 1671 \\
\hline
\end{tabular}

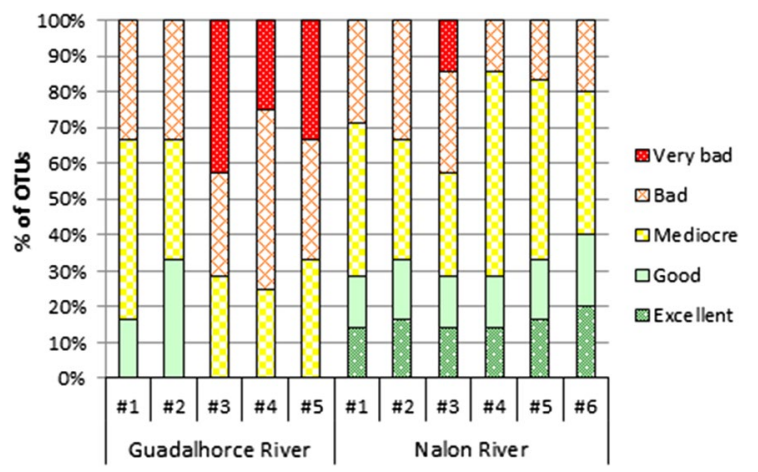

Fig. 3 Proportion of OTUs of different algae indicators of water quality in the sampling points from Guadalhorce and Nalón rivers. Indicators were classified according to the consensus list of this study: Achnanthidium minutissimum excellent; Nitzschia dissipata good; Cocconeis pediculus, Cyclotella meneghiniana, Cymatopleura solea and Surirella angusta mediocre; Caloneis amphisbaena, Mayamaea permitis and Nitzschia palea bad; Entomoneis paludosa, Navicula phyllepta and Navicula veneta very bad

Algae very tolerant to water pollution and eutrophic conditions i.e. indicators of very bad water quality were more abundant downstream and in areas influenced by dams in Guadalhorce River, and in the most impounded location N\#3 in Nalón River (Fig. 3). In the latter, indicators of excellent and good water quality were present in all the samples. Thus, the effect of dams detected on water quality using the indicators chosen in this study was stronger in Guadalhorce than in Nalón River.

In summary, the ecological community and indicators employed in this study revealed a higher degree of ecological disconnection and a lower water quality in dammed areas of the Guadalhorce River than in those from the Nalón River.

Ecosystem services and disservices

The changes in ecosystem services provided by Guadalhorce and Nalón river dams perceived by stakeholders (Supplementary Table 3) are summarized in Table 3. It can be seen that many services exhibited a positive change both above and below dams in Guadalhorce River. In particular, the cultural benefits and the regulation contained many services with positive changes. The catalogue of services scoring higher in this estimation included drinking water and energy supply, entertainment and leisure activities (kayaking, bath), as well as historical sites and cultural patrimony. Examples mentioned were the Caminito del Rey path (Biosphere Prize to Sustainable Tourism, Cultural Patrimony EU Prize Europa Nostra) in the upper zone, and archaeological sites like "Cerro del Villar" in lower reaches. In Nalón River many disservices were found especially below dams (Table 3). The absence of the very appreciated Atlantic salmon in the pristine spawning areas upstream was highlighted.

The average of all the estimated changes in ESS after dam construction was positive in the three categories above and below dams in Guadalhorce River, with the cultural ecosystem services being especially high with near 0.8 points in the both river zones (Fig. 4). In contrast, the change in services caused from Nalón River dams was perceived as 
Table 3 Change in ecosystem services provided by Guadalhorce and Nalón river dams, as perceived by stakeholders

\begin{tabular}{|c|c|c|c|c|}
\hline \multirow{2}{*}{ Category of benefits } & \multicolumn{2}{|l|}{ Guadalhorce } & \multicolumn{2}{|l|}{ Nalón } \\
\hline & Above dams & Below dams & Above dams & Below dams \\
\hline \multicolumn{5}{|l|}{ Provision of material services } \\
\hline Reared animals and their outputs & 0 & 0 & -1 & 0 \\
\hline Wild plants and animals & -1 & -1 & -1 & -1 \\
\hline Aquaculture & 0 & 0 & 0 & 0 \\
\hline Surface water for drinking & 1 & 1 & 1 & 0 \\
\hline Ground water for drinking & 0 & 1 & 0 & 0 \\
\hline Materials/biomass from plants, algae and animals & 0 & 0 & -1 & -1 \\
\hline Surface water for non-drinking purposes & 1 & 1 & 1 & 0 \\
\hline Ground water for non-drinking purposes & -1 & 1 & 0 & 0 \\
\hline Energy & 1 & 1 & 1 & 0 \\
\hline \multicolumn{5}{|l|}{ Regulation } \\
\hline $\mathrm{C}$ sequestration/storage/accumulation by ecosystems & 1 & 0 & 1 & 0 \\
\hline Dilution by water & 1 & 1 & 0 & 1 \\
\hline Mediation of smell/noise/visual impacts & 1 & 1 & -1 & -1 \\
\hline Erosion protection & 0 & -1 & 0 & -1 \\
\hline Flood protection & 0 & -1 & 0 & 1 \\
\hline Hydrological cycle and water flow maintenance & 1 & 1 & 0 & 1 \\
\hline Drought prevention & 1 & 1 & 1 & 0 \\
\hline Soil formation-decomposition and fixing processes & 0 & 0 & 1 & 0 \\
\hline Micro and regional climate regulation & 1 & 1 & 1 & 0 \\
\hline Chemical condition of freshwaters & 0 & 1 & -1 & -1 \\
\hline Maintaining nursery populations and habitats & 0 & 0 & -1 & -1 \\
\hline \multicolumn{5}{|l|}{ Cultural services } \\
\hline $\begin{array}{l}\text { Experiential use of plants, animals and landscapes in different } \\
\text { environmental settings }\end{array}$ & 0 & 0 & 0 & 0 \\
\hline Physical use of landscapes in different environmental settings & 1 & 1 & 1 & 1 \\
\hline Scientific & 1 & 1 & 0 & 0 \\
\hline Educational & 1 & 1 & 1 & 1 \\
\hline Heritage, cultural & 1 & 1 & -1 & 0 \\
\hline Entertainment & 1 & 1 & 1 & 0 \\
\hline Aesthetic & 1 & 1 & -1 & 0 \\
\hline Symbolic & 1 & 1 & 0 & 0 \\
\hline Sacred and/or religious & 0 & 0 & 0 & 0 \\
\hline
\end{tabular}

Categories: provision of material services, regulation, cultural services $(0,1$ and -1 represent the change in ecosystem services (after-before) regarding dams construction)

negative, principally in provision of material goods and regulation below dams. The difference between the two rivers summarized in Fig. 4 evidences a greater appreciation of dams by the consulted stakeholders in the dry Mediterranean Málaga province than in Asturias region, of temperate humid Atlantic climate, although objective ecological indicators show a more deteriorated ecological status of the dammed area of Guadalhorce River than that of Nalón River.

A total of $\mathrm{N}=300$ (59\% females, $27 \%$ reservoir users) and 319 (58\% females, $42 \%$ reservoir users) interviews were conducted in Nalón and Guadalhorce rivers respectively. Raw data are presented in Supplementary Table 4. In the question about the dam acceptance $0.3 \%$ of respondents thought they 


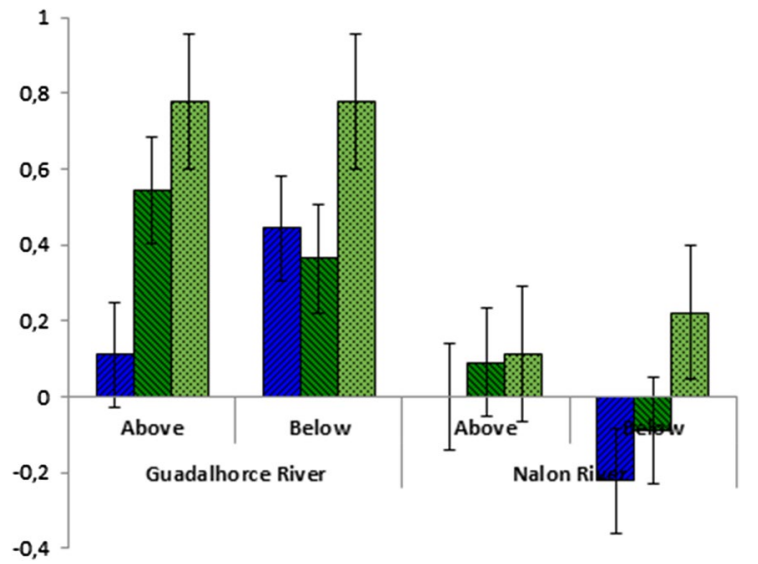

Fig. 4 Mean estimates of change in provision, regulation and cultural services provided upstream and downstream by Guadalhorce River dams. SE as capped bars

should be eliminated, $3.8 \%$ would prefer them out of their living area and $38.5 \%$ believed they should be modified for having less ecological impact, while the opinion of $12.6 \%$ of participants was they should be maintained as they are today, and $44.8 \%$ though that more dams and reservoirs are needed to provide more services. This demonstrates a majority of participants supporting current dams in the Guadalhorce River, $57.4 \%$, while the level of rejection was $4.1 \%$ of participants. Regarding dam acceptance in Nalón River, the proportion of participants choosing each of the five options offered was: They should be eliminated, 1\%; I would prefer them out of the area where I am living, $10.3 \%$; Should be modified for having less ecological impact, 45.7\%; Should be maintained as they are today, 20.3\%; More dams and reservoirs are needed to provide more services, $22.7 \%$. These results show an acceptance or increase of current dams by $43 \%$ of the participants (lower than in Guadalhorce River), and a rejection by $11.3 \%$ (higher than in Guadalhorce River).

Regarding the willingness to pay more taxes for different actions improving ecosystem services on Guadalhorce River dams and reservoirs, the one least economically supported by the participants was the demolition of dams (Fig. 5). For this action $31 \%$ of participants would not increase their taxes at all, and less than $50 \%$ would give more than $0.5 \%$ of taxes increase. In contrast, improving river connectivity and constructing new dams and reservoirs were options supported in the region. More than $70 \%$ of participants would increase their taxes by more than $0.5 \%$ for them. This is coherent with a high appreciation of dams and reservoirs and the ecosystem services perceived by stakeholders, as shown above. Respondents from Asturias about Nalón River dams provided similar answers to the construction of fish scales, supported less the actions to improve river connectivity and also the construction of new dams and reservoirs (Fig. 5).

In addition to the differences between rivers regarding the willingness to pay for different services, there were differences between the users of the dams (inhabiting nearby or frequent visitors using reservoir services) and general population in the willingness to pay for some of the proposed actions. Users would
Fig. 5 Proportion of participants willing to increase their taxes by a percentage for different actions on Guadalhorce and Nalón rivers dams

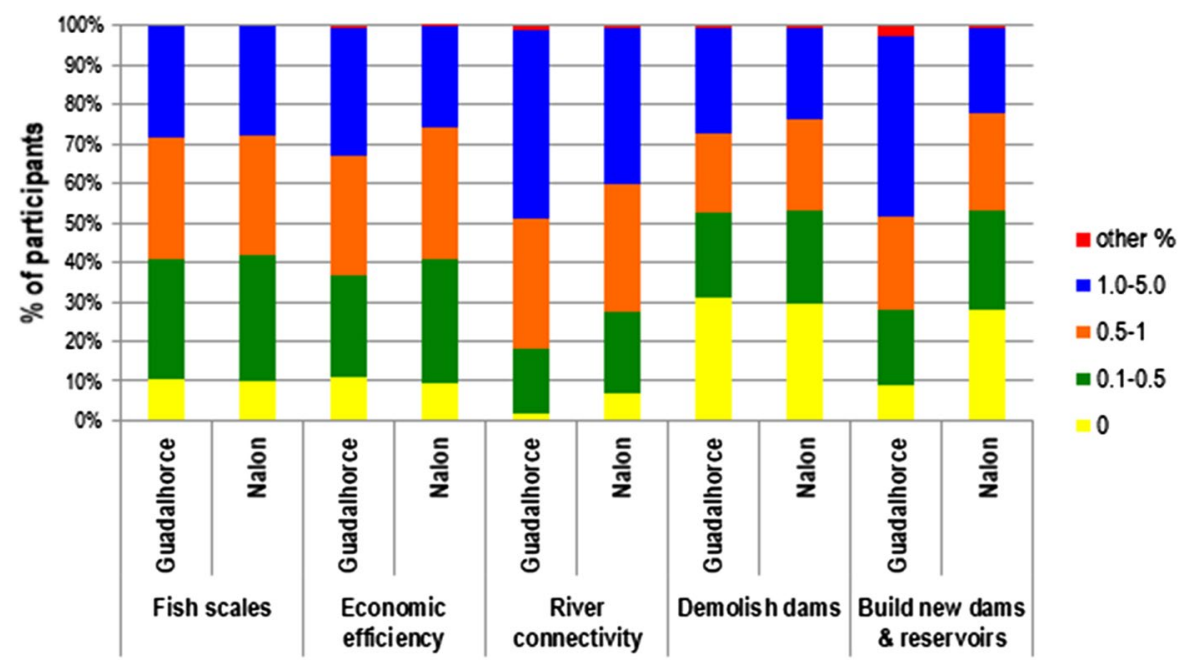


pay significantly more taxes than indirect users (general population) to improve the economic efficiency of dams and reservoirs, and also for connectivity, and will pay less to demolish obsolete dams, especially the users of Guadalhorce River dams (Table 4).

Indeed, the differences between regions (Asturias versus Málaga) for the improvement of connectivity and building more dams, both attracting more willingness to pay in Guadalhorce River, were highly significant with F-values having $\mathrm{p}<<0.001$ (Table 4).

\section{Discussion}

This study, although limited to two river cases, has a wide significance because many results can be extrapolated to other regions. Drastic reduction of water quality in dammed river areas has been already reported in other regions and previous research (Quevedo et al. 2018; Fernández et al. 2019b), and indeed is confirmed in this study based on phytoplankton. The differences between better conserved upstream sites and the sites affected by dams that contain more indicators of poor ecosystem health may be considered as a call of attention downstream.

However, and despite reduced water quality and connectivity, dams and reservoirs are appreciated by the population and especially by the river users; many would increase their taxes to build even more dams and reservoirs, especially in the dry Mediterranean region targeted in this study. The higher appreciation of dams and reservoirs services found in Málaga was consistently associated with more willingness to pay for the construction of new dams. Opposite to other studies where residents in dammed areas are opposed to reservoir construction (Wiejaczka et al. 2018; Hoominfar and Radel 2020), the users and residents in the two case studies were more favourable to dams and intervention on dams than the general population. In addition to the undeniable use of the reservoirs for different applications, noticeably drinking water and energy, this could be due to the old age of the reservoirs that made them a part of the landscape for the present generations.

On the other hand, algae communities seem to be disconnected in the rivers studied, as algae and animal communities are in many other rivers affected by dams in Europe and worldwide (Aparicio et al. 2000; Santos et al. 2017; van Puijenbroek et al. 2018). The importance of river connectivity for local populations is highlighted in our results, where almost one half of the participants in the survey chose improving connectivity as an action worthy to increase significantly their annual taxes. This action would increase the number of species allowing migratory species to reach the reservoirs located in the upper river reaches, thus enhancing recreational uses like fishing that are included in the well-perceived cultural services of Guadalhorce River reservoirs. The construction of passages for aquatic organisms to pass the dams and reconnect populations along Guadalhorce River should be further discussed under the light of these discoveries and considered as an investment in environmental health.

The application of respectful and environmentally responsible strategies for river management

Table 4 Mean (standard deviations) of tax increases that dam/reservoir users and general population of the two regions studied would accept to improve dams and reservoir services of Guadalhorce and Nalón rivers

\begin{tabular}{lllclc}
\hline & Fish scales & Economic efficiency & Connectivity & Demolition & Building more dams \\
\hline $\begin{array}{lllll}\text { Asturias } \\
\text { General }\end{array}$ & $2.78(0.94)$ & $2.64(0.89)$ & $3.05(0.92)$ & $2.43(1.1)$ & $2.56(1.09)$ \\
Users & $2.7(1.05)$ & $3.09(1.03)$ & $3.11(1.02)$ & $2.4(1.3)$ & $2.03(1.14)$ \\
Málaga & & & & \\
General & $2.86(0.94)$ & $2.79(1.02)$ & $3.22(0.83)$ & $2.63(1.14)$ & $3.06(0.99)$ \\
Users & $2.65(1.02)$ & $2.95(1.01)$ & $3.42(0.79)$ & $2.18(1.23)$ & $3.25(1.1)$ \\
Factor region & 0.03 & 1.66 & $11.4^{* * *}$ & 0.07 & $70.6^{* * *}$ \\
Factor use & 3.2 & $13.02^{* * *}$ & $5.55^{*}$ & $6.7 * *$ & 0.001 \\
Interaction & 0.64 & 3.2 & 1.1 & $4.5^{*}$ & $16.8^{* * *}$ \\
\hline
\end{tabular}

Below, $\mathrm{F}(1,613)$ values for the factors region, use and their interaction. *, ** and $* * *$ for $\mathrm{p}<0.05,0.01$ and 0.001 respectively 
would be especially important in the lower reach of Guadalhorce River. Relatively high proportion of bad ecosystem health bioindicators emphasizes the need of controlling the urban wetland of Málaga city (Site\#5) which protection figure should be at least maintained or upgraded. Guadalhorce wetland, situated in this place, is already a special protection area (SPA) for migratory birds and it is important to highlight its dune vegetation. It contains species that are almost extinct from other littoral places of the region, as Medicago marina, Polygonum maritimum, Otanthus maritimus, Pancratium maritimum. Besides that, this place has a variety of native birds, reptiles and amphibians. Perhaps the zone could obtain a higher degree of environmental protection.

In Nalón River the most affected area, of worst water quality, would be around Tanes reservoir. The low health status of this area should be of concern as it is a protected space within the United Nations Educational, Scientific, and Cultural Organization (UNESCO) biosphere reserve of Redes Natural Park. A diverse fauna is contained in this protected space, some protected species as Salmo trutta, Lutra lutra or Galemys pyrenaicus that could be threatened and the status of the Natural Park should be re-evaluated as previously suggested in (Fernández et al. 2019a).

The interdisciplinary approach followed here combines an environmental analysis based on eDNA metabarcoding for the inventory of indicator species, and a social investigation based on participatory research with local stakeholders and a faceto-face local survey. It has to be taken into account that eDNA metabarcoding still has some limitations to overcome. Future studies could follow recently published guidelines for good practices, such as the one published by Bruce et al. (2021). Hopefully, the results of this case study will help to give more value to aquatic ecosystems and river connectivity in dry landscapes such as Mediterranean basins.

\section{Conclusions}

Although ecosystem health was found to be affected due to the presence of dams, generally positive views regarding reservoirs were found in the study of both North and South river basins, being the population from the south the one that showed more acceptance of dams and reservoirs.
Acknowledgements We are grateful to Dania Abdul Malak, Christoph Schröder, Juán Antonio Barberá and José Manuel Nieto López for their help in Málaga research settings.

Funding Open Access funding provided thanks to the CRUE-CSIC agreement with Springer Nature. This study received funding from the European Union's Horizon 2020 Research and Innovation program under Grant Agreement No 689682 (project AMBER), and from the Government of Asturias Principality Grant GRUPIN AYUD/2021/50967. Sara Fernandez holds a Margarita Salas Grant referenced SV-PA-21-AIUD/2021/58385.

Data availability The dataset contained in this MS can be found at Mendeley data repository using the link: http://dx.doi. org/10.17632/kpfvn7jjd9.1\#file-55105a24-2fc4-40e5-b1cbc1c4c837bf87 after publication.

\section{Declarations}

Conflict of interest The authors have no relevant financial or non-financial interests to disclose.

Open Access This article is licensed under a Creative Commons Attribution 4.0 International License, which permits use, sharing, adaptation, distribution and reproduction in any medium or format, as long as you give appropriate credit to the original author(s) and the source, provide a link to the Creative Commons licence, and indicate if changes were made. The images or other third party material in this article are included in the article's Creative Commons licence, unless indicated otherwise in a credit line to the material. If material is not included in the article's Creative Commons licence and your intended use is not permitted by statutory regulation or exceeds the permitted use, you will need to obtain permission directly from the copyright holder. To view a copy of this licence, visit http://creativecommons.org/licenses/by/4.0/.

\section{References}

Aparicio E, Vargas MJ, Olmo JM, de Sostoa A (2000) Decline of native freshwater fishes in a mediterranean watershed on the Iberian Peninsula: a quantitative assessment. Environ Biol Fishes 59:11-19

Ardura A, Borrell YJ, Fernández S, Arenales MG, Martínez JL, Garcia-Vazquez E (2020) Nuisance algae in ballast water facing international conventions. Insights from DNA metabarcoding in ships arriving in Bay of Biscay. Water 12:1-14

Armitage PD, Moss D, Wright JF, Furse MT (1983) The performance of a new biological water quality score system based on macroinvertebrates over a wide range of unpolluted running-water sites. Water Res 17:333-347

Arthington AH, Naiman RJ, McClain ME, Nilsson C (2010) Preserving the biodiversity and ecological services of rivers: New challenges and research opportunities. Freshw Biol 55:1-16 
Baker C (2017) Workflow for generating a qiime-compatible blast database from an entrez search. pp. 1-4

Beck HE, Zimmermann NE, Mcvicar TR, Vergopolan N, Berg A, Wood EF (2018) Data descriptor: present and future Köppen-Geiger climate classification maps at 1-km resolution. Sci Data. https://doi.org/10.1038/sdata.2018.214

Bolyen E, Rideout JR, Dillon MR, Bokulich NA, Abnet CC, Al-Ghalith GA, Alexander H, Alm EJ, Arumugam M, Asnicar F et al (2019) Author correction: reproducible, interactive, scalable and extensible microbiome data science using QIIME 2 (Nature Biotechnology, (2019), 37, 8, (852-857), 10.1038/s41587-019-0209-9). Nat Biotechnol 37:1091

Boyé H, Vivo M (2016) The environmental and social acceptability of dams. Field actions science reports. J Field Actions 2016:14

Bruce K, Blackman RC, Bourlat SJ, Hellström M, Bakker J, Bista I, Bohmann K, Bouchez A, Brys R, Clark K, Elbrecht V, Fazi E, Fonseca VG, Hänfling B, Leese F, Mächler E, Mahon AR, Meissner K, Panksep K, Pawlowski J, Schmidt Yáñez PL, Seymour M, Thalinger B, Valentini A, Woodcock P, Traugott M, Vasselon V, Deiner K (2021) A practical guide to DNA-based methods for biodiversity assessment. Adv Books 1:e68634

Cimarelli L, Singh KS, Mai NTN, Dhar BC, Brandi A, Brandi L, Spurio R (2015) Molecular tools for the selective detection of nine diatom species biomarkers of various water quality levels. Int J Environ Res Public Health 12:5485-5504

Cowart DA, Murphy KR, Cheng CHC (2018) Metagenomic sequencing of environmental DNA reveals marine faunal assemblages from the West Antarctic Peninsula. Mar Genomics 37:148-160

Crook DA, Lowe WH, Allendorf FW, Eros T, Finn DS, Gillanders BM, Hadwen WL, Harrod C, Hermoso V, Jennings $S$ et al (2015) Human effects on ecological connectivity in aquatic ecosystems: integrating scientific approaches to support management and mitigation. Sci Total Environ 534:52-64

Dell'Uomo A, Torrisi M (2009) Freshwater algae and their use for safeguarding the Mediterranean basin. Bocconea 23:93-105

Descy J-P, Coste M (1991) A test of methods for assessing water quality based on diatoms. SIL Proc 1922-2010(24):2112-2116

Edgar RC (2010) Search and clustering orders of magnitude faster than BLAST. Bioinformatics 26:2460-2461

European Environment Agency (2018) Annual Indicator Report Series (AIRS) - In support to the monitoring of the 7th Environment Action Programme. Environmental Indicator Report.

Feio MJ, Aguiar FC, Almeida SFP, Ferreira MT (2012) AQUAFLORA: a predictive model based on diatoms and macrophytes for streams water quality assessment. Ecol Ind 18:586-598

Fernández S, Rodríguez S, Martínez JL, Borrell YJ, Ardura A, García-Vázquez E (2018) Evaluating freshwater macroinvertebrates from eDNA metabarcoding: a river Nalón case study. PLoS ONE 13:e0201741

Fernández S, Arboleya E, Dopico E, Ardura A, Garcia-Vazquez E (2019a) Non-indigenous fish in protected spaces: trends in species distribution mediated by illegal stocking. Aquat Conserv Mar Freshw Ecosyst 29:2240-2252

Fernández S, Rodríguez-Martínez S, Martínez JL, GarciaVazquez E, Ardura A (2019b) How can eDNA contribute in riverine macroinvertebrate assessment? A metabarcoding approach in the Nalón River (Asturias, Northern Spain). Environ DNA 1:385-401

García-Ramos JC, Jiménez-Sánchez M, Piñuela L, Domínguez Cuesta M, López Fernández C (2006) Patrimonio geológico en Asturias: la cuenca alt a del río Nalón y la Cost a de los Dinosaurios. VII Reunión de la Comisión de Patrimonio Geológico: Colunga

Guiry MD, Guiry GM, Morrison L, Rindi F, Valenzuela Miranda S, Mathieson AC, Parker BC, Langangen A, John DM, Bárbara I et al (2014) AlgaeBase: an on-line resource for Algae. Cryptogam Algol 35:105-115

Hammer Ø, Harper DAT, Ryan PD (2013) Past: paleontological statistics software package for education and data analysis. Paleontol Stat Softw Stat 105:1352-1357

Han M, Fukushima M, Kameyama S, Fukushima T, Matsushita B (2008) How do dams affect freshwater fish distributions in Japan? Statistical analysis of native and nonnative species with various life histories. Ecol Res 23:735-743

Hoominfar E, Radel C (2020) Contested dam development in Iran: a case study of the exercise of state power over local people. Sustainability 12:5476

Horreo JL, Martinez JL, Ayllon F, Pola IG, Monteoliva JA, Héland M, Garcia-Vazquez E (2011) Impact of habitat fragmentation on the genetics of populations in dendritic landscapes. Freshw Biol 56:2567-2579

Kelly M, Juggins S, Guthrie R, Pritchard S, Jamieson J, Rippey B, Hirst H, Yallop M (2008) Assessment of ecological status in U.K. rivers using diatoms. Freshw Biol 53:403-422

Kim J, An K-G, Kim JY, An K-G (2015) Integrated ecological river health assessments, based on water chemistry, physical habitat quality and biological integrity. Water 7:6378-6403

Limburg KE, Waldman JR (2009) Dramatic declines in North Atlantic Diadromous fishes. Bioscience 59:955-965

Malmqvist B, Rundle S (2002) Threats to the running water ecosystems of the world. Environ Conserv 29:134-153

Martin M (2011) Cutadapt removes adapter sequences from high-throughput sequencing reads. Embnet. J 17:10

Mcallister DE, Craig JF, Davidson N, Delany S, Seddon M (2001) Biodiversity impacts of large dams. In: International Union for Conservation of Nature and Natural Resources and the United Nations Environmental Programme. pp. 63

McCartney M (2009) Living with dams: managing the environmental impacts. Water Policy 11:121-139

Okuku EO, Tole M, Kiteresi LI, Bouillon S (2016) The response of phytoplankton and zooplankton to river damming in three cascading reservoirs of the Tana River, Kenya. Lakes Reserv Res Manage 21:114-132

Petr BB, Libuše M, Karel O, Markéta B, Jiří Heteša F, Brabcová B, Marvan P, Opatřilová L, Brabec K, Fránková M et al (2017) Diatoms in water quality assessment: to count or not to count them? Hydrobiologia 795:113-127

Port JA, O'Donnell JL, Romero-Maraccini OC, Leary PR, Litvin SY, Nickols KJ, Yamahara M, Kelly RP (2016) Assessing vertebrate biodiversity in a kelp 
forest ecosystem using environmental DNA. Mol Ecol 25(2):527-541

Pringle C (2003) What is hydrologic connectivity and why is it ecologically important? Hydrol Process 17:2685-2689

Quevedo L, Ibanez C, Caiola N, Cid N, Hampel H (2018) Impact of a reservoir system on benthic macroinvertebrate and diatom communities of a large Mediterranean river (lower Ebro river, Catalonia, Spain). LIMNETICA 37:209-228

Reyes-Gavilan FG, Garrido R, Nicieza AG, Toledo MM, Braca F (1996) Fish community variation along physical gradients in short streams of northern Spain and the disruptive effect of dams. Hydrobiologia 321:155-163

Rivera SF, Vasselon V, Jacquet S, Bouchez A, Ariztegui D, Rimet F (2018) Metabarcoding of lake benthic diatoms: from structure assemblages to ecological assessment. Hydrobiologia 807:37-51

Rodeles AA, Galicia D, Miranda R (2017) Recommendations for monitoring freshwater fishes in river restoration plans: a wasted opportunity for assessing impact. Aquat Conserv Mar Freshw Ecosyst 27:880-885

Santos RMB, Sanches Fernandes LF, Cortes RMV, Varandas SGP, Jesus JJB, Pacheco FAL (2017) Integrative assessment of river damming impacts on aquatic fauna in a Portuguese reservoir. Sci Total Environ 601-602:1108-1118

Singh UB, Ahluwalia AS, Sharma C, Jindal R, Thakur RK (2013) Planktonic indicators: a promising tool for monitoring water quality (early-warning signals). Ecol Environ Conserv 19:793-800

Sneddon CS, Barraud R, Germaine MA (2017) Dam removals and river restoration in international perspective. Water Altern 10:648-654 van Puijenbroek PJTM, Buijse AD, Kraak MHS, Verdonschot PFM (2018) Species and river specific effects of river fragmentation on European anadromous fish species. River Res Appl 35:68

Vandenplas C, Loosveldt G (2017) Modeling the weekly data collection efficiency of face-to-face surveys: six rounds of the European Social Survey. J Surv Stat Methodol 5:212-232

Vasselon V, Rimet F, Tapolczai K, Bouchez A (2017) Assessing ecological status with diatoms DNA metabarcoding: scaling-up on a WFD monitoring network (Mayotte island, France). Ecol Ind 82:1-12

von der Ohe PC, Prüss A, Schäfer RB, Liess M, de Deckere E, Brack W (2007) Water quality indices across Europea comparison of the good ecological status of five river basins. J Environ Monit 9:970-978

Wiejaczka Ł, Piróg D, Tamang L, Prokop P (2018) Local residents' perceptions of a dam and reservoir project in the Teesta Basin, Darjeeling Himalayas, India. Mt Res Dev 38:203

World Commission on Dams (2000) Dams and development: a new framework for decision-making: the report of the World Commission on Dams. Earthscan, London

Publisher's Note Springer Nature remains neutral with regard to jurisdictional claims in published maps and institutional affiliations. 